"Mircea cel Batran" Naval Academy Scientific Bulletin, Volume XIX - 2016 - Issue 2

\title{
ANALYSIS OF NOISE AND VIBRATION PRODUCED BY THE EQUIPMENT IN THE REEFER LABORATORY
}

\author{
Tiberiu PAZARA ${ }^{1}$ \\ Mihail PRICOP ${ }^{2}$ \\ lonut-Cristian SCURTU ${ }^{3}$ \\ Codruta PRICOP \\ ${ }^{1}$ Lecturer dr.eng., Naval Academy, Constanta \\ ${ }^{2}$ Captain (N) Associate Professor PhD eng., Naval Academy, Constanta \\ ${ }^{3}$ Ltjg (N) instr.eng., Naval Academy, Constanta \\ ${ }^{4}$ Associate Professor PhD eng., Maritime University, Constanta
}

\begin{abstract}
This paper presents the results of the measurements made in the Reefer simulator from the Naval Academy "Mircea cel Batran“. The vibrations of the equipment were measured using accelerometers mounted in key positions and after that, a correlation between vibration levels in these positions was made. The noise produced in the laboratory was evaluated to determine its influence over the performance of the students during simulations.
\end{abstract}

Keywords: Reefer, vibration, noise, correlation

\section{Introduction}

Containers are the most common method to transport merchandise using ships. For perishable merchandise like meat, fish, vegetables or other merchandise that needs to be transported at a specific temperature, specials containers are used, namely Reefers.

Naval Academy like other naval educational centers has a simulator for reefers where students can learn to operate these special containers. The simulator contains real reefers that operate onboard ships. During the simulations these installations run in similar conditions to the ones onboard and generate a great amount of noise. Thus, the students and also the instructors are exposed to this noise.

This paper deals with the problems of noise exposure, but also with the problems created by the vibrations produced by the equipment. Reefers have components like compressors, electrical fans in order to circulate the cooling agent or the air. These components are the source of the vibrations, vibrations that can reveal fatigue of the equipment, possible malfunctions or improper operating.

2. Noise and vibration measurements

The Reefer simulator consists of 4 installations that are exactly the real interfaces that are mounted to containers and they are completely functional.

For the measurements, 2 reefers were chosen: a Carrier PRIMELINE model (reefer P) and a Carrier THINLINE model (reefer T). Both reefers function by the same principle: a compressor cools down the liquid which is then circulated through the system. Also, the reefers are equipped with fans for the air-cooled condenser section. There are 3 working modes for these reefers: Start-up Mode, Perishable Mode and Frozen Mode [1,2].

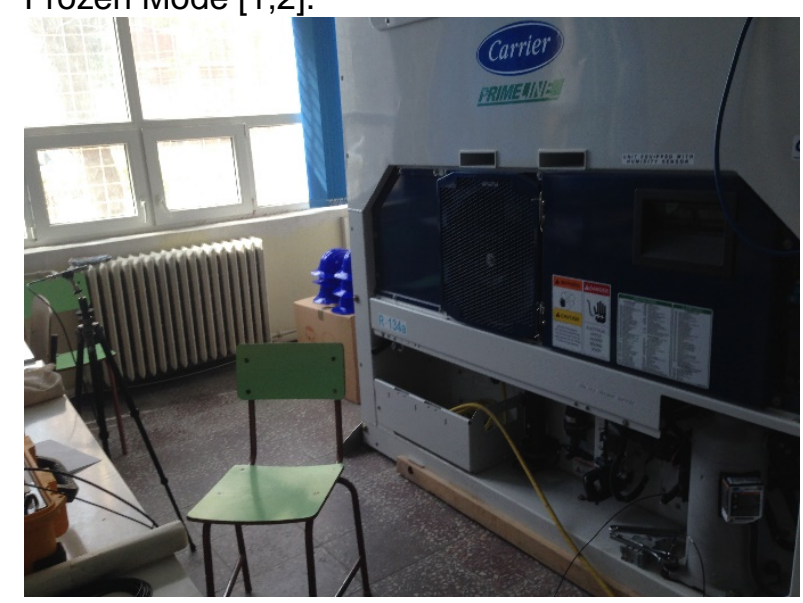

Fig.1

The noise and vibrations were measured during all operating modes of the reefers. Noise was measured with a B\&K omnidirectional microphone type 4189A21 which was placed at $1,2 \mathrm{~m}$ from the floor and at $1,2 \mathrm{~m}$ from the reefers (fig.1). For the reefer $\mathrm{P}$, the vibrations of the compressor were measured using 2 uniaxial accelerometers (B\&K type 752A12) which were placed on the mountings of the compressor (fig.2). In the case of reefer $\mathrm{T}$, the accelerometers were placed just like in the figure 3. 
"Mircea cel Batran" Naval Academy Scientific Bulletin, Volume XIX - 2016 - Issue 2

The journal is indexed in: PROQUEST / DOAJ / Crossref / EBSCOhost / INDEX COPERNICUS / DRJI / OAJI I JOURNAL INDEX / I2OR / SCIENCE LIBRARY INDEX / Google Scholar / Academic Keys/ ROAD Open Access I Academic Resources / Scientific Indexing Services / SCIPIO / JIFACTOR

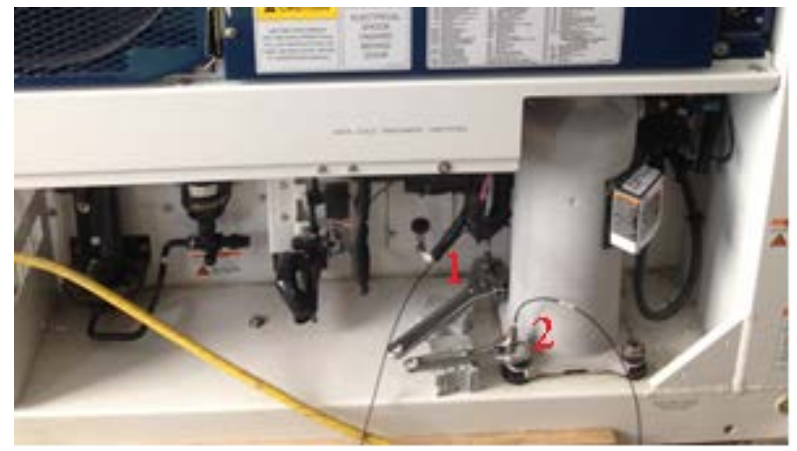

Fig.2 - reefer $\mathbf{P}$

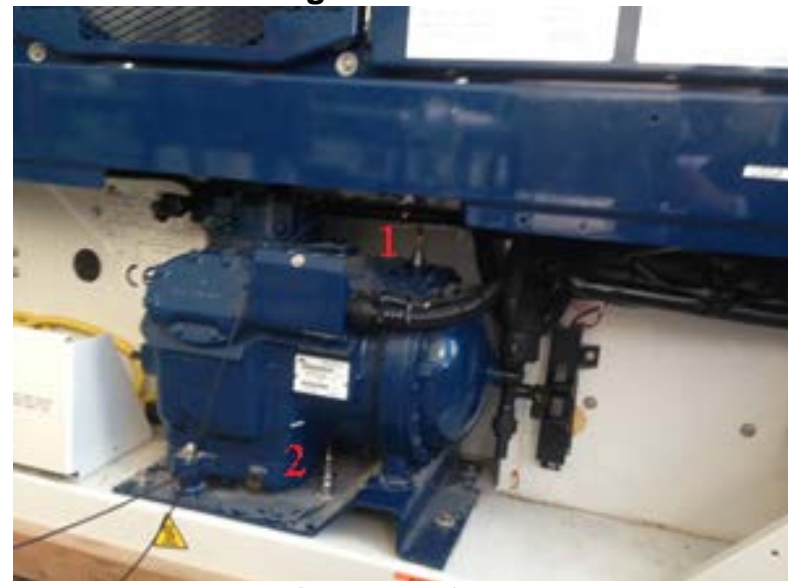

Fig.3 - reefer T

The measuring equipment was completed with the Machine Diagnostics Toolbox 9727 from B\&K. Noise and vibrations were measured simultaneously and the signals were stored on the hard drive of the laptop.

\section{Measurement analysis}

Reefers operate in a constant regime because the merchandise in the containers must be kept at constant parameters. The only variations happens when the equipment goes from one mode to another. That's why it is expected to occur very little variations of noise level and vibrations level.

Vibrations and noise are analyzed using FFT function, Coherence function and, only for noise, CPB function.

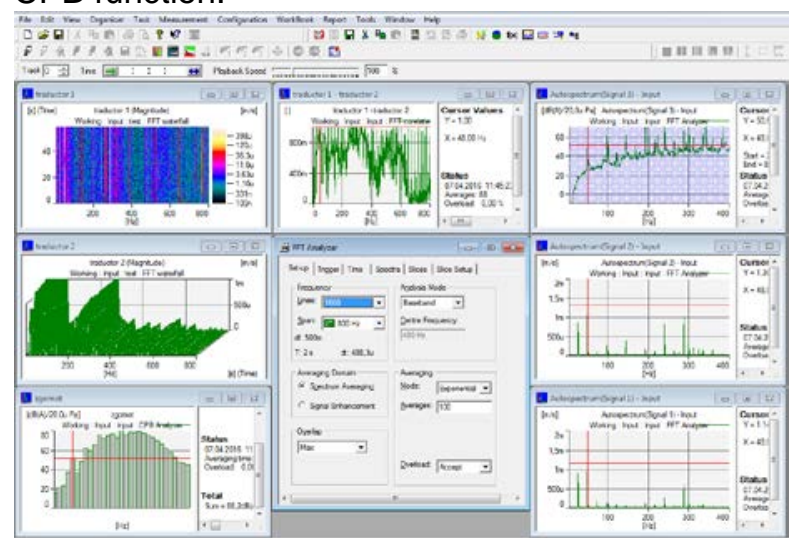

Fig.4- Setup of Pulse Lapshop

The coherence function establish how much of one signal can be found in another signal. The next figures present the coherence between vibrations and between vibrations and noise.

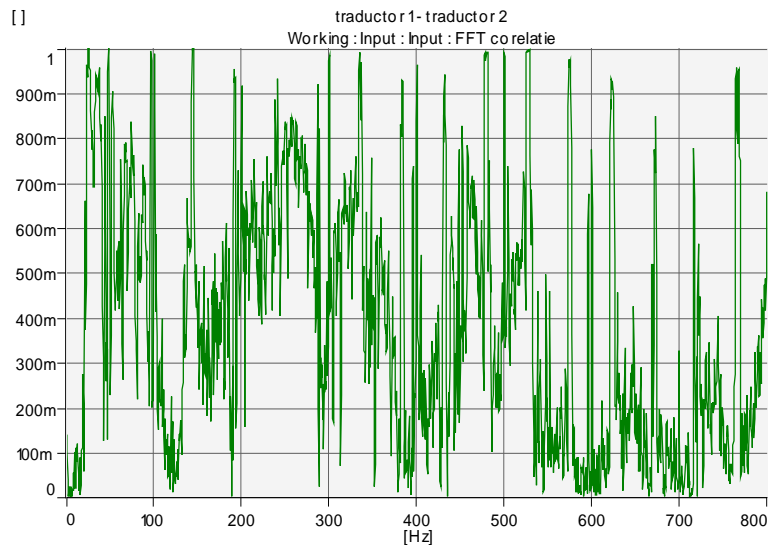

Fig.5 Coherence between vibrations (reefer P)

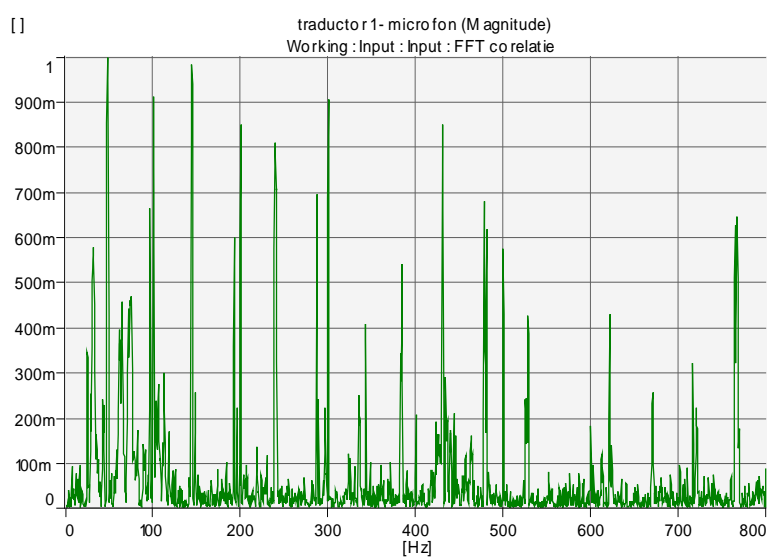

Fig.6 Coherence between vibrations and noise (reefer P)

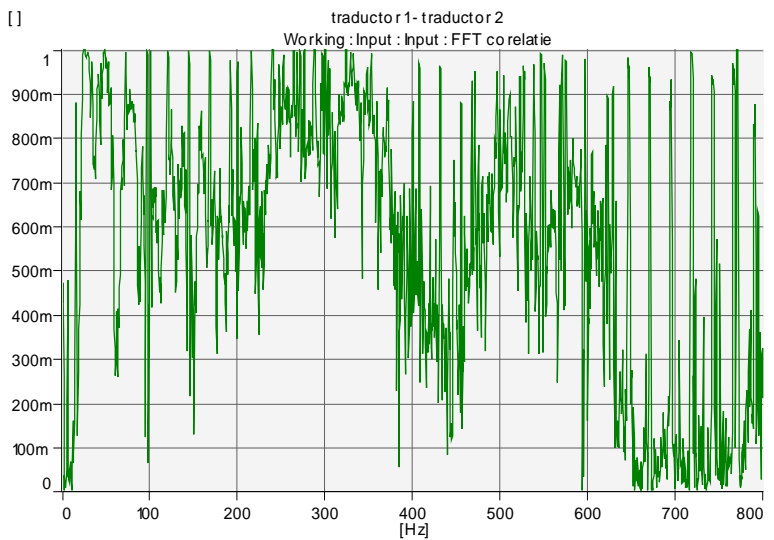

Fig.7 Coherence between vibrations (reefer T) 
"Mircea cel Batran" Naval Academy Scientific Bulletin, Volume XIX - 2016 - Issue 2 The journal is indexed in: PROQUEST / DOAJ / Crossref / EBSCOhost / INDEX COPERNICUS / DRJI / OAJI I JOURNAL INDEX I I2OR / SCIENCE LIBRARY INDEX / Google Scholar / Academic Keys/ ROAD Open Access I Academic Resources / Scientific Indexing Services / SCIPIO / JIFACTOR

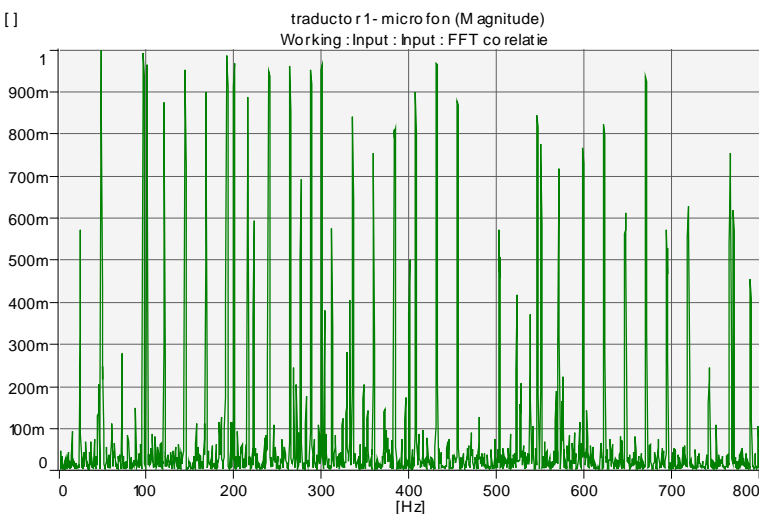

Fig.8 Coherence between vibrations and noise (reefer T)

Most of the time, reefers operate in a normal operation mode, which means no changes. The next pictures present the noise analyzed with CPB (Constant Percentage Bandwidth) function.

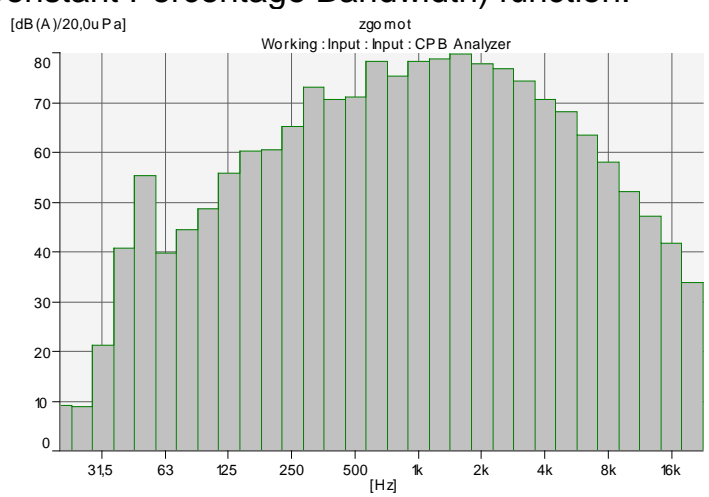

Fig.9 - Noise spectrum of reefer $P$

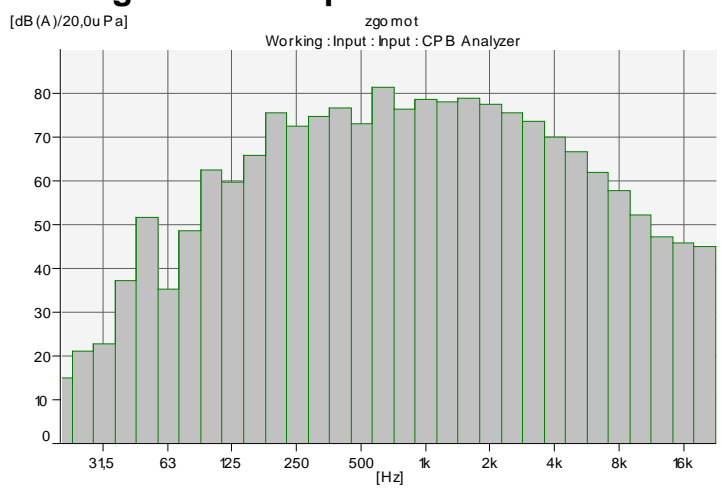

Fig.10 - Noise spectrum of reefer $\mathrm{T}$

\section{Interpretation of results}

For reefer $\mathrm{T}$, the coherence between vibrations is better than the coherence between vibrations of the reefer $P$. The difference is due to the positions where the accelerometers were placed. For reefer $T$ there is no attenuation for the transmitting vibrations, whereas for reefer $\mathrm{P}$, the compressor is mounted on small shock absorbers. Also, due to the material of which are fabricated the compressor and the mountings, the accelerometers had to be fixed using 2 small wrenches. Nevertheless, for fundamental frequencies and harmonics the coherence is 1 or close to 1 value.
Vibration analysis reveals a distinctive spectrum as shown in figures 11 and 12.

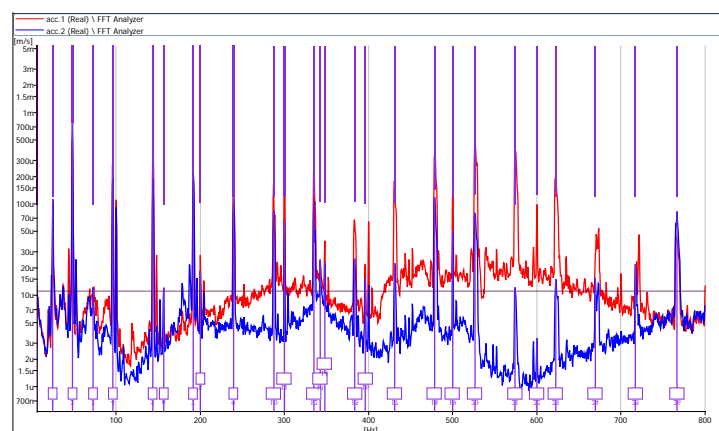

Fig.11 Vibration spectrum for reefer $P$ in normal operation mode

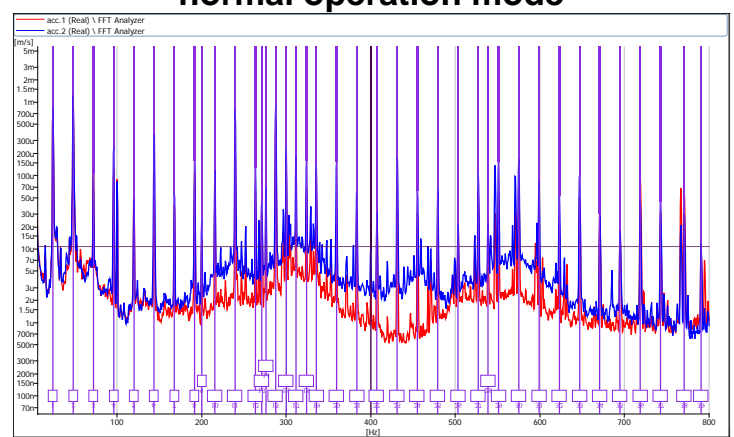

Fig.12 Vibration spectrum for reefer $\mathrm{T}$ in normal operation mode

The system is operating at $50 \mathrm{~Hz}$ AC. The condenser fan motor has a rotating speed of 1425 $\operatorname{RPM}(23,75 \mathrm{~Hz})$ and the evaporation fan motor has a rotating speed of $2850 \operatorname{RPM}(47,50 \mathrm{~Hz})$ $[1,2]$.

The blade passing frequency can be computed using the following formula:

$$
B P F=\frac{\text { no.blades } * R P M}{60}[\mathrm{~Hz}]
$$

Knowing these frequencies, the peaks of the spectrum in figures 11 and 12 represent the fundamental frequencies and the harmonics for compressor and electric fans:

1 - fundamental frequency of fans

2 - fundamental frequency of compressor

$3-1^{\text {st }}$ order harmonic of fans

$4-1^{\text {st }}$ order harmonic of compressor

In the low-frequency domain, the vibration spectra of reefer $P$ is almost identical for the accelerometers; but for mid-frequencies, the spectra presents a difference of vibration levels because of imperfect mounting of accelerometers. For the reefer $\mathrm{T}$, the spectra for both accelerometers are almost identical.

As for global level, the vibrations of both reefers are below the limit imposed by the standards.

In table 1 are presented the noise levels measured for each reefer running independently.

Table 1 - measured noise level

(c) 2015. This work is licensed under the Creative Commons Attribution-Noncommercial-Share Alike 4.0 License. 


\section{"Mircea cel Batran" Naval Academy Scientific Bulletin, Volume XIX - 2016 - Issue 2 The journal is indexed in: PROQUEST / DOAJ / Crossref / EBSCOhost / INDEX COPERNICUS / DRJI / OAJI / JOURNAL INDEX I I2OR / SCIENCE LIBRARY INDEX / Google Scholar / Academic Keys/ ROAD Open Access I Academic Resources / Scientific Indexing Services / SCIPIO / JIFACTOR}

\begin{tabular}{|c|c|c|c|}
\hline $\mathrm{R}_{1}$ & $\mathrm{R}_{2}$ & $\mathrm{R}_{3}$ & $\mathrm{R}_{4}$ \\
\hline 87,2 & 88,2 & 87,7 & 88,3 \\
\hline
\end{tabular}

For multiple noise sources, the equivalent noise level is computed with:

$$
L_{p}=10 \lg \left(10^{\frac{L_{p 1}}{10}}+10^{\frac{L_{p 2}}{10}}+10^{\frac{L_{p 3}}{10}}+10^{\frac{L_{p 4}}{10}}\right)
$$

A calculus was made with formula (1) to determine the noise level produced if two or more reefers are running simultaneously (table 2 ).

Table 2 - computed noise level

\begin{tabular}{|c|c|}
\hline & Noise level (dBA) \\
\hline $\mathrm{R}_{1}+\mathrm{R}_{2}$ & 90,73 \\
\hline $\mathrm{R}_{1}+\mathrm{R}_{2}+\mathrm{R}_{3}+\mathrm{R}_{4}$ & 93,89 \\
\hline
\end{tabular}

The noise produced by each reefer running independently has approximately the same level. This means that the students are exposed to the same amount of noise no matter which reefer is running.

In a lecture hall or in a classroom, the allowed noise level is $45 \mathrm{~dB}(\mathrm{~A})[3,4,8]$. From this point of view, the noise in the laboratory is well over the limit from the standards. This means that the communication between the professor/instructor and the students is very poor. Also, the noise level is close to the 8 hour exposure limit of $90 \mathrm{~dB}(\mathrm{~A})$ stipulated by OSHA (Occupational Safety and Health Administration), and is above the $87 \mathrm{~dB}(\mathrm{~A})$ limit stipulated by Romanian laws $[5,6]$. When a single reefer is running, the noise level is below the limit. But when two or all four reefers are running, the noise limit exceed the limit.

Onboard ships, standards stipulate a $85 \mathrm{~dB}(\mathrm{~A})$ limit for workshops and other work spaces and a $110 \mathrm{~dB}(\mathrm{~A})$ limit for machinery spaces not continuously manned [7]. Reefers are transported on deck of the ships and in storage compartments of the ships. On deck, sound waves dissipate rapidly so the personnel is not exposed to such high noise levels. But in storage compartments, ventilators are running to prevent reefers from overheating. These ventilators represent additional noise sources that increase the noise level. In these compartments (spaces not continuously manned) the noise limit is $110 \mathrm{~dB}(\mathrm{~A})$. In both cases, it is recommended that the personnel should wear protection gear (helmets, earplugs).

Comparing the simulator conditions with the ones onboard ships it can be concluded that students/future navigators are exposed to high noise levels. If two or more levels are running, then the noise level is increasing (table 2). And accordingly, the allowed exposure time to noise is decreasing.Also, when the reefers are operating in frozen mode, noise level in high-frequency domain is increasing which affects more the hearing and the comfort of the participants to the simulations.

\section{CONCLUSIONS}

The noise level of each reefer was determined and the question that is raised, is whether too much noise is for students or not. From these measurements,it can be concluded that students in reefer laboratory are exposedto a noise level above the limit of $87 \mathrm{~dB}(\mathrm{~A})$ [5]. This recommended dosage means that a person can support over an 8 hour period such noise with minimum side effects. These minimum effects are related to low-frequency domain of noise and a person should recover easy from the exposure. For mid and highfrequency domains the recovering time is longer (up to 4 days) before the effects are gone. The inner ear has a protection system for low-frequency noise, but prolong exposure to high-frequency noise can damage irreversibly the hearing.

This elevated noise level in the simulator can affect the health of the participants. Onboard ships, seafarers wear protection equipment to prevent hearing damage or loss. The authors recommend that the simulations in the Reefer laboratory should be carried out in conditions similar to the ones onboard: the students and instructors should wear earplugs for short-time exposure to noise or helmets for long-time exposure to noise.

\section{BIBLIOGRAPHY}

[1] *** T-246 ThinLine Carrier Transicold - Operation and Service Manual

[2] *** T-340 PrimeLine Carrier Transicold - Operation and Service Manual

[3] *** Normativprivindprotecția la zgomot, Ministerul Transporturilor, Construcțiilor și Turismului

[4] *** C 125-2013 Normativprivindacusticaînconstrucțiiși zone urbane

[5] *** Ghidde securitate și sănătate în muncă privind expunerea lucrătorilor la zgomot, Institutul Național de Cercetare-Dezvoltare pentru Protecția Muncii „Alexandru Darabonț", 2013

[6] *** SR ISO 1999:1996 Acustică. Determinarea expunerii la zgomot profesional și estimarea deteriorării auzului

[7] *** IMO I817E Code on noise levels on board ships, 2014 Edition

[8] Eggenschwiler K.: Lecture Halls - Room Acoustics and Sound Reinforcement, Forum Acusticum 2005, Budapest 